\title{
Zinc, zinc transporters and diabetes
}

\author{
J. Rungby
}

Received: 8 March 2010 /Accepted: 23 April 2010/Published online: 21 May 2010

(C) Springer-Verlag 2010

\begin{abstract}
The role of zinc in islet function has recently achieved new attention as a consequence of the identification of zinc transporter 8 (ZNT8) in islets, and the association of mutations in the gene for this zinc transporter with glucose intolerance and type 2 diabetes. ZNT8 is also an autoantigen associated with the appearance of type 1 diabetes. A number of experimental models have been employed to suggest how ZNT8 and other zinc transporters regulate beta cell insulin processing and possibly secretion. An additional role for the zinc transporters in regulating alpha cell function has been suggested. In this issue of Diabetologia, Wijesekara and colleagues, using a cell-specific Znt8 (also known as Slc30a8) knockout model, demonstrate that beta cell insulin processing and glucose tolerance is negatively affected after beta cell knock out of Znt8, whereas Znt8 knockout in alpha cells seems to have little effect on glucagon secretion or glucose tolerance. Although we are yet to see the therapeutic potential of these new findings, the area represents a field through which manipulation of islet function may eventually be possible.
\end{abstract}

Keywords Alpha cell $\cdot$ Beta cell $\cdot$ Diabetes $\cdot$ Zinc $\cdot$ Zinc transporters

$\begin{array}{ll}\text { Abbreviations } \\ \text { SLC30A8 } & \begin{array}{l}\text { Solute carrier family } 30 \text { [zinc transporter], } \\ \text { member } 8\end{array} \\ \text { ZNT8 } & \text { Zinc transporter } 8\end{array}$

J. Rungby $(\triangle)$

Departments of Endocrinology and Pharmacology,

Aarhus University Hospital,

Tage-Hansensgade,

DK-8000 Aarhus C, Denmark

e-mail: jr@farm.au.dk
In the present edition of Diabetologia, Wijesekara and colleagues [1] further explore the functional role of zinc transporter 8 (ZNT8) (which is also known as solute carrier family 30 [zinc transporter], member 8 [SLC30A8]) in alpha and beta cells. In a series of elegant experiments the authors show that beta cell-specific knockout of Znt8 (also known as Slc30a8) causes glucose intolerance and that this is accompanied by alterations in intracellular zinc metabolism and granule morphology in knockout beta cells. Suppression of a number of transcription factors (including pancreatic and duodenal homeobox 1 [PDX1]) needed for normal beta cell function is also a consequence of Znt8 knockout. By contrast, specific knockout of Znt8 in alpha cells seems not to affect glycaemic status or glucagon secretion.

\section{Zinc and diabetes}

As a devoted supporter of an intimate relationship between metals and disease, Paracelsus (1493-1541) was the first to describe the metal zinc. Since 1934 it has been known that zinc permits the formation of insulin crystals; two or more zinc atoms cause insulin to crystallise in hexamers [2]. We know that zinc-deficient animals have a lack of insulin in beta cells [3].

Alterations in zinc homeostasis appear to be related to diabetes: hyperzincuria seems well documented in both type 1 and type 2 diabetes and may be influenced by both sex and glycaemic status [4,5]. Plasma zinc may be low (type 2 diabetes) or high (type 1 diabetes) [6]. Zinc supplementation may improve clinical outcomes related to glycaemia in diabetes (reviewed by Jansen et al. [6]). 


\section{Zinc and cells of the endocrine pancreas}

Recent years have brought a deeper understanding of the many roles of zinc in both beta and alpha cells. This development has been further sparked by the identification of mutations in the ZNT8 gene as risk factors for the development of type 2 diabetes as first described by Sladek et al. [7] and since confirmed by several others (for a recent meta-analysis see Jing et al. [8]). Interestingly, ZNT8 has also been identified as an autoantigen in many cases of type 1 diabetes [9].

Zinc is known to be insulinomimetic [10] and now a number of experiments have added new information and improved our knowledge. Zinc is co-secreted with insulin and other granule substances. Co-secretion of zinc has substantial paracrine or autocrine effects. First, zinc participates in the regulation of beta cell mass; cosecreted zinc causes beta cell death, an effect that may be attenuated by pyruvate or clioquinol [11-13]. Second, zinc may mediate some of the suppressive effects of beta cells on glucagon secretion from neighbouring alpha cells [14-16], but some controversy remains on this subject [17]. Finally, cytokine exposure seems to influence the production of zinc-transporting proteins, suggesting an interaction between zinc fluxes and traditional beta cell toxic substances [18].

\section{The role of zinc transporters}

Beta cells, particularly beta cell granules, are extremely rich in zinc, therefore an active transport against concentration gradients is required in order to maintain adequate zinc concentrations. Some transport of zinc into beta cells occurs through L-type voltage-gated calcium channels [19]. Perhaps more importantly, zinc homeostasis is regulated by the ZNT and ZIP zinc transporters. In general, the ZNTs (SLC30A family) transport zinc from the cytoplasm to extracellular spaces or to intracytoplasmic vacuoles, such as secretory granules, while the ZIPs (SLC39A family) are thought to increase cytoplasmic zinc.

The characterisation by Chimienti and colleagues of ZNT8 [20] as a zinc transporter primarily located in beta cells has allowed several mechanisms to be described that may explain the relationship between mutations in the ZNT8 gene and the risk for type 2 diabetes. More specifically, the risk allele causes beta cell dysfunction in patients with type 2 diabetes $[21,22]$. Overexpression of ZNT8 increases the zinc content of beta cells and promotes glucose-stimulated insulin secretion in cultured cells; it also protects from apoptosis related to zinc depletion without inducing the toxic effects of the increased level of intracellular zinc [23]. ZNT8 expression is downregulated by interleukin 1-beta, which is known to affect beta cell function in type 2 diabetes [18]. Global knockout of Znt8 renders mice glucose intolerant with impaired insulin secretion, although not all results have been concordant [24 26]. In all reports the consequences of Znt8 knockout seem to be relatively benign; for further details, see Rutter [27]. In knockout mice a high-fat diet causes severe insulin resistance, possibly related to a differential expression of Znt 8 in varying types of adipose tissue [28]. Results from the present study [1], which used selective beta cell knockout, support the increasing body of literature that suggests that ZNT8 is important for insulin processing and secretion.

\section{Perspectives}

Are other zinc transporters relevant for the study of diabetes? Apparently so: ZNT3, also downregulated by interleukin 1-beta [18], may be important for adequate beta cell function as knockout causes accelerated glucose intolerance in streptozotocin-treated animals [29].

Is zinc metabolism a future therapeutic target? We have yet to see larger clinical trials exploring the therapeutic potential of this new knowledge. However, several paths may lead towards therapy. Metallothioneins may be one way to go. Metallothioneins can be induced by zinc and may contribute significantly to the regulation of organ function as shown in experimental diabetic cardiomyopathy, possibly via their interactions with both intra- and extracellular zinc [30].

The formation of amyloid beta, known to cause beta cell death if it aggregates in islets, may be another area of focus. Zinc, via the activity of ZNT3, seems pivotal for the formation of amyloid beta in the nervous system [31], a process that occurs in parallel in islets and that may hopefully be interfered with-by the use of metallothioneins or other means - in the future in order to maintain functional beta cells.

The identification of ZNT8 as a risk factor for type 2 diabetes and the description of the pathologies related to this protein, such as those described in this month's Diabetologia, may offer new means for protecting beta cell mass and function.

Duality of interest The author declares that there is no duality of interest associated with this manuscript.

\section{References}

1. Wijesekara N, Dai FF, Hardy AB et al. Beta cell-specific Znt8 deletion in mice causes marked defects in insulin processing, crystallisation and secretion. Diabetologia. doi:10.1007/s00125010-1733-9

2. Scott DA (1934) Crystalline insulin. Biochem J 28:1592-1602 
3. Huber AM, Gershoff SN (1973) Effect of zinc deficiency in rats on insulin release from the pancreas. J Nutr 103:1739-1744

4. McNair P, Kiilerich S, Christiansen C et al (1981) Hyperzincuria in insulin treated diabetes mellitus-its relation to glucose homeostasis and insulin administration. Clin Chim Acta 112:343348

5. Kinlaw WB, Levine AS, Morley JE et al (1983) Abnormal zinc metabolism in type 2 diabetes mellitus. Am J Med 75:273-277

6. Jansen J, Karges W, Rink L (2009) Zinc and diabetes - clinical links and molecular mechanisms. J Nutr Biochem 20:399-417

7. Sladek R, Rocheleau G, Rung J et al (2007) A genome-wide association study identifies novel risk loci for type 2 diabetes. Nature 445:881-885

8. Jing YL, Sun QM, Bi Y, Shen SM, Zhu DL (2010) SLC30A8 polymorphism and type 2 diabetes risk: evidence from 27 study groups. Nutr Metab Cardiovasc Dis. doi:10.1016/j.numecd. 2009.11.004

9. Wenzlau JM, Juhl K, Yu L et al (2007) The cation efflux transporter ZnT8 (Slc30A8) is a major autoantigen in human type 1 diabetes. Proc Natl Acad Sci U S A 104:17040-17045

10. Yoshikawa Y, Ueda E, Miyake $\mathrm{H}$ et al (2001) Insulinomimetic bis (maltolato)zinc(II) complex: blood glucose normalizing effect in KK-A(y) mice with type 2 diabetes. Biochem Biophys Res Commun 281:1190-1193

11. Chang I, Cho N, Koh JY, Lee MS (2003) Pyruvate inhibits zincmediated pancreatic islet cell death and diabetes. Diabetologia 46:1220-1227

12. Kim BJ, Kim YH, Kim S et al (2000) Zinc as a paracrine effector in pancreatic islet cell death. Diabetes 49:367-372

13. Priel T, Aricha-Tamir B, Sekler I (2007) Clioquinol attenuates zinc-dependent beta-cell death and the onset of insulitis and hyperglycemia associated with experimental type I diabetes in mice. Eur J Pharmacol 565:232-239

14. Ishihara H, Maechler P, Gjinovci A, Herrera PL, Wollheim CB (2003) Islet beta-cell secretion determines glucagon release from neighbouring alpha-cells. Nat Cell Biol 5:330-335

15. Franklin I, Gromada J, Gjinovci A, Theander S, Wollheim CB (2005) Beta-cell secretory products activate alpha-cell ATPdependent potassium channels to inhibit glucagon release. Diabetes 54:1808-1815

16. Slucca M, Harmon JS, Oseid EA, Bryan J, Robertson RP (2010) ATP-sensitive $\mathrm{K}+$ channel mediates the zinc switch-off signal for glucagon response during glucose deprivation. Diabetes 59:128134

17. Ravier MA, Rutter GA (2005) Glucose or insulin, but not zinc ions, inhibit glucagon secretion from mouse pancreatic alphacells. Diabetes 54:1789-1797
18. Egefjord L, Jensen JL, Bang-Berthelsen $\mathrm{CH}$ et al (2009) Zinc transporter gene expression is regulated by pro-inflammatory cytokines: a potential role for zinc transporters in beta-cell apoptosis? BMC Endocr Disord 9:7

19. Gyulkhandanyan AV, Lee SC, Bikopoulos G, Dai F, Wheeler MB (2006) The $\mathrm{Zn}^{2+}$-transporting pathways in pancreatic beta-cells: a role for the L-type voltage-gated $\mathrm{Ca}^{2+}$ channel. J Biol Chem 281:9361-9372

20. Chimienti F, Devergnas S, Favier A, Seve M (2004) Identification and cloning of a beta-cell-specific zinc transporter, ZnT-8, localized into insulin secretory granules. Diabetes 53:2330-2337

21. Staiger H, Machicao F, Schäfer SA et al (2008) Polymorphisms within the novel type 2 diabetes risk locus MTNR1B determine $\beta$-cell function. PLoS ONE 3:e3962

22. Kirchhoff K, Machicao F, Haupt A (2008) Polymorphisms in the TCF7L2, CDKAL1 and SLC30A8 genes are associated with impaired proinsulin conversion. Diabetologia 51:597-601

23. Chimienti F, Devergnas S, Pattou F et al (2006) In vivo expression and functional characterization of the zinc transporter ZnT8 in glucose-induced insulin secretion. J Cell Sci 119:4199-4206

24. Nicolson TJ, Bellomo EA, Wijesekara $\mathrm{N}$ et al (2009) Insulin storage and glucose homeostasis in mice null for the granule zinc transporter ZnT8 and studies of the type 2 diabetes associated variants. Diabetes 58:2070-2083

25. Lemaire K, Ravier MA, Schraenen A et al (2009) Insulin crystallization depends on zinc transporter ZnT8 expression, but is not required for normal glucose homeostasis in mice. Proc Natl Acad Sci U S A 106:14872-14877

26. Pound LD, Sarkar SA, Benninger RK et al (2009) Deletion of the mouse Slc30a8 gene encoding zinc transporter 8 results in impaired insulin secretion. Biochem J 421:371-376

27. Rutter GA (2010) Think zinc; new roles for zinc in the control of insulin secretion. Islets 2:49-50

28. Smidt K, Pedersen SB, Brock B et al (2007) Zinc-transporter genes in human visceral and subcutaneous adipocytes: lean vs obese. Mol Cell Endocrinol 264:68-73

29. Smidt K, Jessen N, Petersen AB et al (2009) SLC30A3 responds to glucose and zinc variations in $\beta$-cells and is critical for insulin production and in vivo glucose metabolism during $\beta$ cell stress. PLoS ONE 4:e5684

30. Wang J, Song Y, Elsherif L et al (2006) Cardiac metallothionein induction plays the major role in the prevention of diabetic cardiomyopathy by zinc supplementation. Circulation 113:544-554

31. Stoltenberg M, Bush AI, Bach G et al (2007) Amyloid plaques arise from zinc-enriched cortical layers in APP/PS1 transgenic mice and are paradoxically enlarged with dietary zinc deficiency. Neuroscience 150:357-369 